\title{
THERAPEUTIC EFFECTS OF FLUNITRAZEPAN IN DYSTONIAS AND TORTICOLLIS
}

\author{
PRELIMINARY COMMUNICATION
}

RAUL MARINO Jr**, REINA BENABOU**, SALOMON BENABOU * * *

\begin{abstract}
SUMMARY - A new form of clinical treatment is proposed for dystonias and torticollis using flunitrazepan (FN), a powerful agonist of all benzodiazepine receptors of GABA neurons. FN has a specific effect in dystonic patients, specially those in which the hypnotic effect of this drug is absent or diminished, thus suggesting the existence of two different neurochemical categories of dystonias.
\end{abstract}

KEY WORDS: dystonia, torticollis, flunitrazepan, benzodiazepine receptors.

Efeitos terapêticos do flunitrazepan em distonias e torcieolo: comunicạão preliminar.

RESUMO - Nova forma de tratamento clinico é proposta para distonias e torcicolo usando flunitrazepan (FN), poderoso agonista de todos os receptores: benzodiazepínicos de neurônios GABA. FN tem efeito específico em pacientes distônicos, especialmente naqueles em que o efeito hipnótico dessa droga está ausente ou diminuído, sugerindo assim a existência de duas diferentes categorias neuroquímicas de distonias.

PALAVRAS-CHAVE: distonia, torcicolo, flunitrazepan, receptores benzodiazepinicos.

Dystonia is a form of striatal familial dyskinesia transmitted in a recessive autosomical way, clinicaily manifested by several symptoms as: segmental dystonias, torsion spasms or attitudinal tremor. These symptoms may be influenced pharmacologically by certain drugs like dopamine and anticholinergic antiparkinsonian drugs. It is well-known that the majority of the benzodiazepine group has no specific effects on dystonias, although they are commonly prescribed.

Patients. Results. Since 1973 we have observed a group of 35 patients, who have been submitted to varying doses of a currently used hypnotic drug: Flunitrazepan (FN) RO 5-4200, which, differently from other benzodiazepines we found as having definite and specific effects on dystonia and torticollis cases. A detailed study of the latter 15 cases using the Fahn-Marsden movement and disability scale 1 and video-recording, has shown that there is an inverse correlation between the hypnotic effects of this medication and its antidystonic action. 'Thus, the patients that had a good response, with amelioration of their dystonic gyndrome did not show the typical somnolence as expected normally with the use of FN. On the contrary, some have presented an insomnia effect. According to the Fahn-Marsden scale these patients have reached a statistical level of amelioration between 32 and $100 \%$. The lower amelioration rates

* M.D., Professor and Chairman, Division of Neurosurgery, Department of Neurology, Hospital das Clínicas (HC), University of São Paulo Medical School (FMUSP); ** M.D., Assistant Physician, Division of Functional Neurosurgery (DFN), HC, FMUSP; ** M.D., Director, DFN, HC, FMUSP. Aceite: 4-março-1993.

Dr. Raul Marino Jr. - Rua Dr. Ovidio Pires de Campos s/n - 05403-010 São Paulo SP - Brasil. 
were observed in those patients in which FN produced its habitual hypnotic effects, even with lower doses. Due to this latter effects, drowsiness has prevented these patients trom receiving higher doses, necessary to control their symptoms (up to $40 \mathrm{mg}$ or twenty $2 \mathrm{mg}$ tablets per day, was necessary in one patient). The group without somnolence during daytime had an amelioration averaging between 64 land $100 \%$. The group with severe drowsiness during the day and at night had an amelioration averaging between $32 \%$ and 58\%, according to the same scale.

Comments. These findings can be explained by the fact that GABA is the main neuronal inhibitor transmitter, and different subtypes of GABA receptors appear to exist in vertebrate brain with related gene sequence producing specific tissue families of receptors, resulting from different oligomeric combinations 3 . The affinity of benzodiazepines for binding on GABA - A receptors provides the explanation for their mechanism of action. FN is a powerful agonist of all benzodiazepine receptors of GABA neurons. Its action is particularly important in the neurons of pars reticulata of substantia nigra, which receives the striatonigral GABA ergic pathway. The neurons of the pars reticulata are, on the other hand, source of the nigro-thalamic pathway 2 .

In conclusion, we propose that FN has a particular pharmacological action in specific benzodiazepinc receptors. This study suggests that a specific type of receptors should play an important role in the control of sleep, whereas another type of receptors would act more specifically in the control of involuntary movements. Since dystonia is a genetically conditioned disorder, resulting from the lack of inhibition of motor neurons of the basal ganglia, lack of function of one or more GABA receptors subtypes appears as a possible explanation. We also suggest that the dystonic syndrome may be due to two different types of genetical biochemical dysfunction of those receptors. The apparent specificity of FN tor a particular group of dystonic patients, namely those in which the hypnotic action is absent or diminished, suggests the existence of two different neurochemical categories of dystonia. It is important to emphasize that, in two cases, there was a complete suppression of dystonic symptoms after discontinuation of medication, one of them remaining without FN for the last five years. No tolerance or hallucinatory phenomena were observed during the treatment. On the contrary, amelioration persisted after lowering of the higher dosages. Comparative video-recording throughout the treatment will give the impression that the gain that controls the intensity of the disease process can be manipulated as a dial with this drug until the syndrome decreases in volume and interisity.

Furthermore, we propose this newly found therapeutic effect of Flunitrazepan as an important alternative to a number of functional neurosurgical procedures, which usually provide only partial on temporary relief of these severe neurological syndromes.

\section{REFERENCES}

1. Burke RE, Fahn S, Marsden CD et al. Validity and reliability of a rating scale for the primary torsion dystonias. Neurology 1985, 35:73-77.

2. Mereu G, Biggio G. Differential action of various allosteric modulators of GABA-A receptors upon the spontaneous discharge rate of nigral neurons "in vivo". In Biggio G, Costa $E$, eds): Gaba and benzodiazepine receptor subtypes. New York: Raven Press, 1990, p $109-125$.

3. Olsen RW, Bureau M, Khrestchatisky $\mathbf{M}$ et al. Isolation of pharmacologically distinct Gaba-benzodiazepine receptor by protein chemistry and molecular cloning. In Biggio C, Costa E (eds): Gaba and benzodiazepine receptor subtypes. New York: Raven Press, 1990, 35-49. 